Meta

Journal des traducteurs

Translators' Journal

\title{
F. Scott Fitzgerald's Die Schönen und Verdammten: A Corpus-based Study of Speech-act Report Verbs as a Feature of Translators' Style
}

\section{Marion Winters}

Volume 52, numéro 3, septembre 2007

URI : https://id.erudit.org/iderudit/016728ar

DOI : https://doi.org/10.7202/016728ar

Aller au sommaire du numéro

Éditeur(s)

Les Presses de l'Université de Montréal

ISSN

0026-0452 (imprimé)

1492-1421 (numérique)

Découvrir la revue

Citer cet article

Winters, M. (2007). F. Scott Fitzgerald's Die Schönen und Verdammten: A Corpus-based Study of Speech-act Report Verbs as a Feature of Translators' Style. Meta, 52(3), 412-425. https://doi.org/10.7202/016728ar
Résumé de l'article

L'objectif de la présente recherche est d'identifier les caractéristiques du style des traducteurs, en comparant deux traductions allemandes du The Beautiful and Damned de F. Scott Fitzgerald, toutes deux publiées en 1998. Les verbes de narration sont étudiés comme éléments potentiels des styles individuels des traducteurs. L'analyse du corpus est facilitée par l'utilisation d'outils de manipulation. L'étude se conclut par des commentaires sur l'usage différent de la répétition et d'alternances ainsi que leurs effets. 


\title{
F. Scott Fitzgerald's Die Schönen und Verdammten: A Corpus-based Study of Speech-act Report
Verbs as a Feature of Translators' Style
}

\author{
MARION WINTERS \\ Dublin City University, Dublin, Ireland \\ marion.winters@dcu.ie
}

\begin{abstract}
RÉSUMÉ
L'objectif de la présente recherche est d'identifier les caractéristiques du style des traducteurs, en comparant deux traductions allemandes du The Beautiful and Damned de F. Scott Fitzgerald, toutes deux publiées en 1998. Les verbes de narration sont étudiés comme éléments potentiels des styles individuels des traducteurs. L'analyse du corpus est facilitée par l'utilisation d'outils de manipulation. L'étude se conclut par des commentaires sur l'usage différent de la répétition et d'alternances ainsi que leurs effets.
\end{abstract}

\begin{abstract}
The aim of the present paper is to identify features of translators' style, comparing two German translations of F. Scott Fitzgerald's The Beautiful and Damned, both published in 1998. Speech-act report verbs are investigated as potential elements of the individual styles of the translators. Corpus analysis is facilitated by the use of corpus processing tools. The paper concludes with comments on the translators' different usage of repetition versus variation and their effects.

MOTS-CLÉS/KEYWORDS

corpora, F. Scott Fitzgerald, repetition, speech acts, speech-act report verbs
\end{abstract}

Properly speaking,

there is no such thing as Style; there are merely styles, that is all.

Oscar Wilde

\section{Aims and structure of the paper}

This paper aims to investigate the styles of the two German translators of F. Scott Fitzgerald's novel The Beautiful and Damned - Renate Orth-Guttmann and HansChristian Oeser. Orth-Guttmann and Oeser both published translations of Fitzgerald's novel in 1998 under the title Die Schönen und Verdammten, thus presenting the researcher with a unique opportunity to compare the styles of two translators while keeping constant many other factors in the translation process, namely source text and author, time of publication of original and translation and source and target language. For present purposes style is understood as 'preferred or recurring patterns of linguistic behaviour, rather than individual or one-off instances of intervention' (Baker 2000: 245). An obvious type of recurring patterns is repetition at the lexical level. In this paper I focus on repetition - and variation - in the translators' use of 
speech-act report verbs. Speech acts and speech-act report verbs are explained in section Two below. Section Three describes the methodology applied in the study and section Four presents the analyses and results. The paper concludes with possible interpretations of the findings (section Five) and final remarks on these results (section Six).

\section{Speech acts and speech-act report verbs}

A speech act is 'an utterance that constitutes some act in addition to the mere act of uttering' (Collins 1994) and a performative is defined as 'denoting an utterance that constitutes some act, esp. the act described by the verb’ (Collins 1994). Austin (1976 [1962]), generally considered the father of speech-act theory, introduced the term 'performative verbs.' These verbs appear in the utterance itself and have either the form of: (i) first person singular, indicative, active, present (e.g. 'I warn you.'); or (ii) second or third person, singular or plural, indicative, passive, present (e.g. 'You/ passengers are warned to...'). The utterances in which these verbs occur perform an action, over and above the actual utterance (e.g. the act of warning). For further detailed discussion of happy and unhappy performative utterances, as well as explicit as opposed to primary performative verbs see Austin (1976 [1962]; I-VII).

According to Austin (1976 [1962]), all these performative utterances have an illocutionary force. This means that the performed act (illocution) has a function (force). While the locutionary act merely accounts for the act of uttering, the illocutionary act includes the action. However, usually any speech act has been uttered for some reason and therefore has some communicative function. This means that most locutionary acts are also illocutionary acts and they basically become one category. The other category is the perlocutionary act which accounts for the consequential effects of the speech act.

Among the locutionary acts Austin distinguishes between phonetic acts, merely accounting for 'the act of uttering certain noises' (Austin 1976 [1962]: 95), rhetic acts (indirect speech acts) and phatic acts. According to Austin, phatic acts are mimicable and reproducible. One can mimic not merely the statement in quotation marks, but also the more complex way in which the statement was made (Austin 1976 [1962]: 95). Austin describes phatic acts as 'the 'inverted commas' use of 'said' as we get it in novels: every utterance can be just reproduced in inverted commas, or in inverted commas with 'said he' or, more often, 'said she'2, \&c., after it' (Austin 1976 [1962]: 96).

In Short et al's (1996) speech classification these phatic acts are called direct speech (acts). Short distinguishes between speech and thought, direct and indirect speech/thought, and the narrator's representation of speech/thought acts. Direct speech is divided into the categories of free direct speech/thought, i.e. speech/thought without a reporting clause, and what I will call reported direct speech/thought, defined as appearing with a reporting clause. ${ }^{3}$ The present paper is concerned with reported direct speech acts. As narrator's representation is only marginally concerned with speech, it is not discussed any further here. In addition, all classes of thought acts as well as indirect speech acts are omitted, as they can have different illocutionary or perlocutionary forces to those associated with direct speech, such as the effect of distancing the reader from the speaker.

Reported direct speech acts consist of a reported clause, which appears in inverted commas, and a reporting clause. The reporting clause, which contains the relevant 
verb, can occur in initial, mid or end-position. In order to exclude borderline cases and ensure a consistent selection of verbs, reporting clauses in this study must end with a colon, when they occur in initial position.

Reporting verbs are those that appear outside the inverted commas in written utterances presenting direct speech. Burgess (2000) calls these verbs 'words introducing direct speech.' Ballmer and Brennenstuhl (1981) speak of 'speech act verbs' using the term 'in the more general sense' and defining it 'to specify the content or means of expression of the linguistic activity' in inverted commas. I find the designation 'speech act verb' for the reporting verb, i.e. the verb outside the inverted commas, ambiguous, especially given Austin's (1976 [1962]) treatment of the subject. Therefore, I follow Bourne (2002) who names these verbs 'speech-act report verbs.' Regarding the speech acts proper I follow Short et al's (1996) terminology and will refer to the utterance in inverted commas as the 'reported clause,' which contrasts with the 'reporting clause' which introduces or follows the direct speech.

As opposed to Austin's performative verbs, Ballmer and Brennenstuhl consider as speech-act report verbs all verbs designating any kind of (aspect of) speech activity (Ballmer and Brennenstuhl 1981: 16). This means that they account for all verbs which can possibly appear in the reporting clause surrounding direct speech. These are the verbs relevant for the present paper. Therefore, I follow Ballmer and Brennenstuhl's methodology for extracting speech-act report verbs. If a verb is inserted in the sentence frame below and if the sentence then makes sense, the verb is counted as a speech-act report verb.

Someone [verb, past tense]: '....' (Ballmer and Brennenstuhl 1981: 16).

(1) Someone said: '....'

(2) ${ }^{\star}$ Someone seemed: '...'?

Sentence (1) makes sense, therefore said is a speech-act report verb whereas sentence (2) is not possible, thus seemed is not a speech-act report verb.

\section{Methodology}

The aligned parallel corpus consists of F. Scott Fitzgerald's novel The Beautiful and Damned and its two German translations, both entitled Die Schönen und Verdammten. Wordsmith Tools (Scott 1998) and Multiconcord (Woolls 1997) were used to facilitate corpus analysis. A frequency wordlist was created with Wordsmith Tools for The Beautiful and Damned. The speech-act report verbs were manually extracted from the wordlist according to the methodology suggested by Ballmer and Brennenstuhl (1981) and speech-act report verbs that occurred a minimum of 15 times were considered.

In some instances, the selected speech-act report verbs did not actually introduce or follow an utterance; these occurrences were excluded. Thus only the occurrences where the verbs appeared in reported direct speech acts, according to Short's classification (see section Two), were selected. These selection criteria brought the frequency of occurrence down to one or two for some verbs. As the present study attempts to investigate potential patterns of translators' habits, rather than unique uses of linguistic features, only the speech-act report verbs occurring in a reported direct speech act a minimum of ten times were considered. The selected speech-act report verbs and their frequencies in The Beautiful and Damned are listed in Table 1. 
TABLE 1

Most frequent speech-act report verbs in The Beautiful and Damned

\begin{tabular}{|l|l|}
\hline Most frequent speech-act report verbs & No. occurrences in reported direct speech \\
\hline said & 174 \\
\hline cried & 53 \\
\hline continued & 28 \\
\hline demanded & 26 \\
\hline answered & 25 \\
\hline suggested & 25 \\
\hline began & 22 \\
\hline asked & 20 \\
\hline added & 18 \\
\hline murmured & 17 \\
\hline inquired & 15 \\
\hline exclaimed & 14 \\
\hline interrupted & 13 \\
\hline called & 12 \\
\hline agreed & 12 \\
\hline whispered & 12 \\
\hline remarked & 11 \\
\hline repeated & 11 \\
\hline insisted & 10 \\
\hline Total & $\mathbf{5 1 8}$ \\
\hline & \\
\hline
\end{tabular}

Multiconcord (Woolls 1997) was used to run parallel concordances for each of the verbs shown in Table 1 in each of the translations.

The speech-act report verbs that the two translators used were analyzed from different angles. First, the number of different translations for each of the speech-act report verbs in Table 1 was investigated. Second, the verbs which each translator used only once for each of the speech-act report verbs were examined. Third, the verbs which each translator used most frequently as a translation of the speech-act report verbs under investigation were analyzed. The analysis of these most frequently used speech-act report verbs in the German translations led to a qualitative analysis of these cases, investigating whether the options chosen were also the most obvious. Finally, the instances where the translators did not opt for the obvious translation were examined with regard to the semantic meaning of the alternative verb used.

\section{Analysis and results}

Table 2 shows the most frequent speech-act report verbs and their total numbers of occurrence in The Beautiful and Damned and the number of different verbs each of the translators uses to translate the English verbs. Orth-Guttmann uses a wider variety 
of verbs than Oeser for all but one verb. The exception is the verb whispered, which Oeser translates with three different verbs, flüsterte (9 times), wisperte (twice) and murmelte (once), while Orth-Guttmann chooses only flüsterte (11 times) and hauchte (once). The most striking example is the verb said, which Orth-Guttmann translates with 27 different verbs, whereas Oeser uses only seven. In the case of cried, OrthGuttmann chooses six times as many verbs as Oeser and makes twelve different choices, while Oeser uses only two different verbs. There are four cases in which Oeser sticks to only one verb, while Orth-Guttmann uses a variety of verbs. The verbs translated with least variety by Orth-Guttmann are asked, called and whispered (2 options), and demanded and inquired (3 options). In most cases Orth-Guttmann uses more than five alternatives, whereas Oeser uses more than five different verbs in only two cases (said and suggested). In total, Oeser translates with fewer than half as many different verbs as Orth-Guttmann.

TABLE 2

Number of different translations for the selected speech-act report verbs

\begin{tabular}{|l|l|l|}
\hline \multirow{2}{*}{ Most frequent speech-act report verbs } & No. different verbs in the translations \\
\cline { 2 - 3 } & Oeser & Orth-Guttmann \\
\hline said (174) & 7 & $\mathbf{2 7}$ \\
\hline cried (53) & 2 & $\mathbf{1 2}$ \\
\hline continued (28) & 2 & 6 \\
\hline demanded (26) & 3 & 3 \\
\hline answered (25) & 5 & 6 \\
\hline suggested (25) & 8 & 8 \\
\hline began (22) & 5 & 7 \\
\hline asked (20) & 2 & 2 \\
\hline added (18) & 5 & 6 \\
\hline murmured (17) & $\mathbf{1}$ & 6 \\
\hline inquired (15) & 3 & 3 \\
\hline exclaimed (14) & 2 & 8 \\
\hline interrupted (13) & $\mathbf{1}$ & 4 \\
\hline called (12) & $\mathbf{1}$ & 2 \\
\hline agreed (12) & 3 & 5 \\
\hline whispered (12) & 3 & 2 \\
\hline remarked (11) & $\mathbf{1}$ & 7 \\
\hline repeated (11) & 2 & 4 \\
\hline insisted (10) & 3 & 10 \\
\hline Total 518 & $\mathbf{5 9}$ & $\mathbf{1 2 8}$ \\
\hline & & \\
\hline
\end{tabular}

The figures in Table 2 indicate that Orth-Guttmann translates with more variety, whereas Oeser uses more repetition. This finding prompts a more detailed analysis of the extent to which the two translators repeat their chosen verbs. Table 3 shows the 
number of verbs each translator uses only once to translate the most frequent speechact report verbs in The Beautiful and Damned, i.e. the choices per verb which they do not repeat. Orth-Guttmann uses 20 verbs only once to translate said. The highest number of verbs used only once by Oeser is six for suggested and four for said. For seven of the speech-act report verbs examined Oeser repeats all his choices, and for eight more verbs there is only one option each, which he does not repeat. OrthGuttmann, however, always chooses a variety of verbs - on average four - to translate the verbs under investigation. In the case of insisted, she does not repeat any of her choices, but instead uses ten different verbs for ten instances of insisted, which Oeser translates with three different verbs. The total number of occurrences shows that OrthGuttmann uses verbs without repetition nearly four times more often than Oeser.

TABLE 3

Number of verbs the translators use only once per speech-act report verb in The Beautiful and Damned

\begin{tabular}{|l|l|l|}
\hline \multirow{2}{*}{ Most frequent speech-act report verbs } & No. verbs in the translations used only once \\
\cline { 2 - 3 } & Oeser & Orth-Guttmann \\
\hline said (174) & $\mathbf{4}$ & $\mathbf{2 0}$ \\
\hline cried (53) & 1 & 6 \\
\hline continued (28) & 1 & 5 \\
\hline demanded (26) & 1 & 2 \\
\hline answered (25) & 2 & 1 \\
\hline suggested (25) & $\mathbf{6}$ & 3 \\
\hline began (22) & - & 3 \\
\hline asked (20) & - & 1 \\
\hline added (18) & 2 & 4 \\
\hline murmured (17) & - & 4 \\
\hline inquired (15) & 1 & 1 \\
\hline exclaimed (14) & 1 & 7 \\
\hline interrupted (13) & - & 2 \\
\hline called (12) & - & 1 \\
\hline agreed (12) & 1 & 2 \\
\hline whispered (12) & 1 & 1 \\
\hline remarked (11) & - & 5 \\
\hline repeated (11) & 1 & 3 \\
\hline insisted (10) & - & $\mathbf{1 0}$ \\
\hline Total 518 & $\mathbf{2 2}$ & $\mathbf{8 1}$ \\
\hline
\end{tabular}

After looking at unique instances of verbs in the translations, the repeated verbs were examined more closely. Table 4 shows the most frequent speech-act report verbs in The Beautiful and Damned and the German verbs they are most frequently translated as, including the frequency of occurrence of each. Only German verbs which were 
used more than three times for the same English verb by at least one of the translators were included in the table. The word 'free' among the verbs signifies the translators' choice of translating a reported direct speech act by a free direct speech act.

TABLE 4

Most frequently used translations for the most frequent speech-act report verbs in The Beautiful and Damned

\begin{tabular}{|c|c|c|c|}
\hline \multirow{2}{*}{$\begin{array}{l}\text { Most frequent speech- } \\
\text { act report verbs }\end{array}$} & \multirow{2}{*}{$\begin{array}{l}\text { Verbs used more than } \\
\text { three times }\end{array}$} & \multicolumn{2}{|c|}{ No. appearances } \\
\hline & & Oeser & Orth-Guttmann \\
\hline said (174) & $\begin{array}{l}\text { sagte } \\
\text { 'free' } \\
\text { fragte } \\
\text { erklärte } \\
\end{array}$ & $\begin{array}{l}165 \\
2 \\
3 \\
-\quad \\
\end{array}$ & $\begin{array}{l}123 \\
14 \\
5 \\
5 \\
\end{array}$ \\
\hline cried (53) & $\begin{array}{l}\text { rief } \\
\text { stieß hervor } \\
\text { sagte } \\
\text { 'free' }\end{array}$ & $\begin{array}{l}52 \\
- \\
1 \\
-\end{array}$ & $\begin{array}{l}7 \\
23 \\
6 \\
7 \\
\end{array}$ \\
\hline continued (28) & fuhr fort & 27 & 23 \\
\hline demanded (26) & $\begin{array}{l}\text { fragte } \\
\text { wollte wissen }\end{array}$ & $\begin{array}{l}13 \\
12 \\
\end{array}$ & $\begin{array}{l}24 \\
1 \\
\end{array}$ \\
\hline answered (25) & $\begin{array}{l}\text { antwortete } \\
\text { erwiderte } \\
\text { 'free' }\end{array}$ & $\begin{array}{l}14 \\
7 \\
-\end{array}$ & $\begin{array}{l}1 \\
11 \\
6\end{array}$ \\
\hline suggested (25) & $\begin{array}{l}\text { schlug vor } \\
\text { sagte } \\
\text { fragte }\end{array}$ & $\begin{array}{l}17 \\
- \\
- \\
\end{array}$ & $\begin{array}{l}6 \\
7 \\
4 \\
\end{array}$ \\
\hline began (22) & $\begin{array}{l}\text { begann } \\
\text { fing an } \\
\text { setzte an } \\
\end{array}$ & $\begin{array}{l}10 \\
5 \\
4 \\
\end{array}$ & $\begin{array}{l}11 \\
3 \\
2 \\
\end{array}$ \\
\hline asked (20) & fragte & 17 & 19 \\
\hline added (18) & fügte hinzu & 10 & 12 \\
\hline murmured (17) & $\begin{array}{l}\text { murmelte } \\
\text { sagte }\end{array}$ & $\begin{array}{l}17 \\
-\end{array}$ & $\begin{array}{l}1 \\
13 \\
\end{array}$ \\
\hline inquired (15) & $\begin{array}{l}\text { fragte } \\
\text { erkundigte sich }\end{array}$ & $\begin{array}{l}5 \\
9 \\
\end{array}$ & $\begin{array}{l}12 \\
1 \\
\end{array}$ \\
\hline exclaimed (14) & $\begin{array}{l}\text { rief } \\
\text { stieß hervor }\end{array}$ & $\begin{array}{l}13 \\
- \\
\end{array}$ & $\overline{7}$ \\
\hline interrupted (13) & $\begin{array}{l}\text { unterbrach } \\
\text { fiel ins Wort }\end{array}$ & $\begin{array}{l}13 \\
-\end{array}$ & $\begin{array}{l}3 \\
8\end{array}$ \\
\hline called (12) & rief & 12 & 11 \\
\hline agreed (12) & $\begin{array}{l}\text { stimmte zu } \\
\text { pflichtete bei } \\
\text { bestätigte }\end{array}$ & $\begin{array}{r}6 \\
5 \\
- \\
\end{array}$ & $\begin{array}{l}1 \\
- \\
6 \\
\end{array}$ \\
\hline whispered (12) & flüsterte & 9 & 11 \\
\hline remarked (11) & $\begin{array}{l}\text { bemerkte } \\
\text { sagte }\end{array}$ & $\begin{array}{l}11 \\
- \\
\end{array}$ & $\begin{array}{l}2 \\
4 \\
\end{array}$ \\
\hline repeated (11) & wiederholte & 10 & 8 \\
\hline insisted (10) & beharrte & 6 & 1 \\
\hline Total 518 & & 470 & 393 \\
\hline
\end{tabular}


In total, Oeser translates $91 \%$ of the verbs under investigation with choices he repeats more than three times, while the verbs Orth-Guttmann repeats that often, account for $76 \%$. For twelve verbs, Oeser's number of appearances is higher than that of OrthGuttmann, which means that he also repeats these frequently used verbs more often than Orth-Guttmann.

There is one particular variation which Orth-Guttmann uses frequently, while it occurs only twice in Oeser's translation, and that is the translation of a reported direct speech act with a free direct speech act. In Orth-Guttmann's translation there are 41 occurrences without a reporting clause in total, distributed across 13 verbs. The highest number of free direct speech acts can be found for the verbs said (14 instances), cried (7 instances) and answered (6 instances), which are among the most frequent speech-act report verbs in The Beautiful and Damned. This could be interpreted as another means by which Orth-Guttmann avoids repetition.

Having examined the most frequently used speech-act report verbs in the translations, the question arises whether they are also the most 'obvious' choices available to the translators. To investigate this question, the main lexical equivalents, taking their function as speech-act report verbs into account, of each of the English verbs were extracted from a bilingual dictionary (Pons 2001) and defined as 'obvious' translations. They are shown in Table 5 along with frequencies in Die Schönen und Verdammten.

TABLE 5

Most frequent speech-act report verbs in The Beautiful and Damned and their obvious translations

\begin{tabular}{|l|l|l|l|}
\hline \multirow{2}{*}{$\begin{array}{l}\text { Most frequent speech- } \\
\text { act report verbs }\end{array}$} & \multirow{2}{*}{ Obvious translations } & Nos. of appearances \\
\cline { 3 - 4 } & & Oeser & Orth-Guttmann \\
\hline said (174) & sagte & 165 & 123 \\
\hline \multirow{2}{*}{ cried (53) } & rief & 52 & 7 \\
& schrie & - & 1 \\
\hline continued (28) & fuhr fort & 26 & 23 \\
\hline demanded (26) & wollte wissen & 12 & 1 \\
\hline \multirow{2}{*}{ answered (25) } & antwortete & 14 & 1 \\
\hline \multirow{3}{*}{ suggested (25) } & erwiderte & 7 & 11 \\
\hline \multirow{2}{*}{ began (22) } & schlug vor & 17 & 6 \\
\hline asked (20) & legte nahe & 2 & - \\
\hline added (18) & unterstellte & 1 & - \\
\hline murmured (17) & fegann & 10 & 11 \\
\hline \multirow{2}{*}{ inquired (15) } & fragte & 5 & 3 \\
\hline exclaimed (14) & fügte hinzu & 17 & 19 \\
\hline interrupted (13) & murmelte & 17 & 12 \\
\hline called (12) & erkundigte sich & 9 & 1 \\
\hline & fragte & 5 & 1 \\
\hline & rief (aus) & 13 & 12 \\
\hline & finterbrach & 13 & - \\
\hline & rief & - & 3 \\
\hline
\end{tabular}




\begin{tabular}{|l|l|l|l|}
\hline agreed (12) & stimmte zu & 6 & 1 \\
\hline whispered (12) & flüsterte & 9 & 11 \\
\hline \multirow{2}{*}{ remarked (11) } & bemerkte & 11 & 2 \\
& sagte & - & 4 \\
\hline repeated (11) & wiederholte & 10 & 8 \\
\hline \multirow{2}{*}{ insisted (10) } & beharrte & 6 & 1 \\
& behauptete & 2 & - \\
\hline Total 518 & & $\mathbf{4 5 1}$ & $\mathbf{2 8 1}$ \\
\hline
\end{tabular}

Oeser chooses the obvious verbs in all cases and often to a great extent or even exclusively (murmured, interrupted, called and remarked). In all but three cases (asked, added and whispered), Oeser makes more use of the obvious translations than Orth-Guttmann. In six cases, Orth-Guttmann uses the obvious translations rarely or not at all. On average, in every third instance, Oeser uses an obvious option where Orth-Guttmann does not. These observations suggest that Oeser not only uses repetition to a greater extent than Orth-Guttmann, but that he also stays closer to the source text.

After looking at the obvious options, the alternative choices of verbs were analyzed. They were examined with regard to their semantic differences in relation to the obvious verbs, which were considered to be equivalent to the English source-text verbs, i.e. literal in recreating the semantic meaning of the source language word in the target text. Some of the alternative translations, such as wisperte for whispered, are equivalent to the obvious options (flüsterte for whispered). Other choices take up a secondary meaning of the English verb, such as empfahl (recommended), legte nahe (advised) and unterstellte (implied/insinuated) for suggested. There are also cases of change in register. For example, in three instances, began is translated as the higher register verb hob an. The most interesting observation is, however, that many of the choices the translators made are different from the source-text verb regarding their semantic meaning. Examples of this would be translations of remarked with staunte (to be amazed), murmured with bestätigte (confirmed) or cried with wiederholte (repeated). Each of these examples shows a shift in the semantic meaning of the source-text verb. It is mainly Orth-Guttmann who uses such verbs with a different semantic element, and this she does on 87 occasions. She uses 33 different verbs which appear as translations for 15 out of the 19 verbs analyzed. Oeser only adds a semantic component in six instances when translating the verbs answered and said. He uses fragte (asked) three times and versetzte (retorted) once for said (sagte). For answered he uses versetzte and beschied (rejected/rebuffed; officialese). In one instance he translates repeated as rief (cried), which slightly changes the semantic meaning. In three instances he translates the verbs cried, added and agreed as sagte (said), which all lack an element of the original semantic meaning. Verbs which lack a semantic element from the source text occur in Orth-Guttmann's translation in 33 instances, distributed across seven verbs, most of them translated as sagte and erklärte (said). These data indicate that Oeser stays closer to the source text and repeats more, while OrthGuttmann deviates more from the source text and uses a greater variety of verbs.

In examining the translations of the speech-act report verb murmured, it is striking that Oeser uses only murmelte, which supports the above hypothesis that he stays closer to the source text. Orth-Guttmann uses the word murmelte only once. In most 
cases she translates murmured as sagte (said, 13 times), which misses out on the component of speaking in a low voice. However, she compensates for this element by using adverbial modification, adding halblaut (half aloud, 9 times) or leise (quietly, 3 times). Another example with modification is the verb agreed, which Orth-Guttmann translates as meinte (said) in three instances; in two of these she adds the adverb zustimmend (in agreement). In the third instance, meinte is not modified; this could be interpreted as a case of implicitation. For the verb repeated, Orth-Guttmann uses jammerte (whined) in one occurrence, which she complements with immer wieder (again and again); the element of pity comes from the source text which reads 'she repeated piteously. The semantic meaning is kept in this example and it does not show explicitation or implicitation. However, there is a slight shift in the focus. In OrthGuttmann's translation, the person in question seems to lament more than in the original.

There is no instance of adverbial or other modification, or motivation from the source text in the cases where Oeser uses a basic speech-act report verb instead of the obvious option, or where he uses verbs with an additional semantic element. These occurrences could be interpreted as cases of explicitation or implicitation, respectively, but there are too few instances to conclude that it would be Oeser's style to implicitate and even less to explicitate.

From the above examples it can be concluded that the instances where OrthGuttmann's choices of speech-act report verbs deviate from the source text cannot as yet be interpreted as instances of explicitation or implicitation. A detailed analysis of the data regarding the source-text influence, as well as possible modifications OrthGuttmann might have used to compensate for the different semantic meanings of her chosen verbs, would be necessary to draw such conclusions.

To illustrate a first step in this further detailed analysis, see the instances of insisted in Table 6.

TABLE 6

The speech-act report verb insisted and its translations in Die Schönen und Verdammten

\begin{tabular}{|c|c|c|c|}
\hline No. & F. Scott Fitzgerald & Oeser & Orth-Guttmann \\
\hline 1 & $\begin{array}{l}\text { C: \MULTIC 1 1 scott.en } \\
\text { P239 S1 } \\
\text { 'I can imagine,' insisted } \\
\text { Anthony, ,a man knowing } \\
\text { too much for his talent to } \\
\text { express. }\end{array}$ & $\begin{array}{l}\text { C: \MULTIC } 1 \backslash \text { scott.de } \\
\text { P239 } \\
\text { 'Ich könnte mir einen } \\
\text { Mann vorstellen', beharrte } \\
\text { Anthony, 'der zuviel weiß, } \\
\text { als daß er es bei seinem } \\
\text { Talent ausdrücken könnte. }\end{array}$ & $\begin{array}{l}\text { C: \MULTIC 1 1 } \text { scott.es } \\
\text { P239 } \\
\text { 'Ich könnte mir vorstellen', } \\
\text { beharrte Anthony, 'daß } \\
\text { jemand über so viel Wissen } \\
\text { verfügt, daß sein Talent } \\
\text { nicht ausreicht, um es } \\
\text { angemessen zu formuli- } \\
\text { eren. }\end{array}$ \\
\hline 2 & $\begin{array}{l}\text { C: \MULTIC 1 1 scott.en } \\
\text { P1757 S1 } \\
\text { 'Why, you read it, Grampa,' } \\
\text { insisted Anthony, some- } \\
\text { what exasperated, ,you } \\
\text { read it and disagreed with } \\
\text { it.' }\end{array}$ & $\begin{array}{l}\text { C: } \backslash \text { MULTIC } 1 \backslash \text { scott.de } \\
\text { P1757 } \\
\text { 'Aber du hast ihn doch } \\
\text { gelesen, Opapa', beharrte } \\
\text { Anthony leicht gereizt, 'du } \\
\text { hast ihn gelesen und warst } \\
\text { anderer Meinung.' }\end{array}$ & $\begin{array}{l}\text { C: \MULTIC } 1 \backslash \text { scott.es } \\
\text { P1757 'Du hast ihn gelesen, } \\
\text { Großpapa', beteuerte } \\
\text { Anthony ein wenig } \\
\text { ungeduldig. <s>'Du hast } \\
\text { ihn gelesen und warst } \\
\text { anderer Meinung.' }\end{array}$ \\
\hline
\end{tabular}




\begin{tabular}{|c|c|c|c|}
\hline 3 & $\begin{array}{l}\text { C: \MULTIC 1 \scott.en } \\
\text { P931 S1 } \\
\text { 'The deuce you don't,' he } \\
\text { insisted. }\end{array}$ & $\begin{array}{l}\text { C: } \backslash \text { MULTIC 1 } 1 \text { scott.de } \\
\text { P931 } \\
\text { 'Von wegen, Sie wissen es } \\
\text { nicht', behauptete er. }\end{array}$ & $\begin{array}{l}\text { C: \MULTIC 1 } \backslash \text { scott.es } \\
\text { P931 } \\
\text { 'Red keinen Unsinn! } \\
\text { Natürlich ist er in dich } \\
\text { verliebt. ...' ‘..' [free] }\end{array}$ \\
\hline 4 & $\begin{array}{l}\text { C: \MULTIC 1 \scott.en } \\
\text { P606 S1 } \\
\text { 'You're a young idiot!' he } \\
\text { insisted wildly. }\end{array}$ & $\begin{array}{l}\text { C: } \backslash \text { MULTIC } 1 \backslash \text { scott.de } \\
\text { P606 'Sie sind ein junger } \\
\text { Dummkopf!' behauptete } \\
\text { er ungestüm. }\end{array}$ & $\begin{array}{l}\text { C: } \backslash \text { MULTIC } 1 \backslash \text { scott.es } \\
\text { P606 } \\
\text { 'Sie sind eine junge Närrin', } \\
\text { widersprach er stürmisch. } \\
\text { [contradicted] }\end{array}$ \\
\hline 5 & $\begin{array}{l}\text { C: \MULTIC 1 \scott.en } \\
\text { P1384 S1 } \\
\text { 'You'd have to in this town,' } \\
\text { insisted Gloria with ready } \\
\text { sophistry. }\end{array}$ & $\begin{array}{l}\text { C: } \backslash \text { MULTIC } ~ 1 \backslash \text { scott.de } \\
\text { P1384 'In diesem Kaff } \\
\text { müßte man das', beharrte } \\
\text { Gloria mit schlagfertiger } \\
\text { Spitzfindigkeit. }\end{array}$ & $\begin{array}{l}\text { C: \MULTIC } 1 \backslash \text { scott.es } \\
\text { P1384 } \\
\text { 'Hier müßtest du das tun', } \\
\text { konterte Gloria schlagfer- } \\
\text { tig. [countered] }\end{array}$ \\
\hline 6 & $\begin{array}{l}\text { C: \MULTIC 1 1 scott.en } \\
\text { P3045 S1 } \\
\text { 'Pour me another drink,' } \\
\text { she insisted. }\end{array}$ & $\begin{array}{l}\text { C: \MULTIC 1 } \text { scott.de } \\
\text { P3045 } \\
\text { 'Schenken Sie mir ein', } \\
\text { beharrte sie. }\end{array}$ & $\begin{array}{l}\text { C: } \backslash \text { MULTIC } 1 \backslash \text { scott.es } \\
\text { P3045 } \\
\text { 'Schenk mir noch was ein', } \\
\text { verlangte sie. [demanded] }\end{array}$ \\
\hline 7 & $\begin{array}{l}\text { C: \MULTIC 1\scott.en } \\
\text { P2055 S2 } \\
\text { Set me down, Dick! I'm } \\
\text { dizzy!' she insisted. }\end{array}$ & $\begin{array}{l}\text { C: } \backslash \text { MULTIC 1 } \backslash \text { scott.de } \\
\text { P2055 } \\
\text { 'Laß mich los, Dick! Mir } \\
\text { ist schwindelig!' beteuerte } \\
\text { sie. }\end{array}$ & $\begin{array}{l}\text { C: } \backslash \text { MULTIC } 1 \backslash \text { scott.es } \\
\text { P2055 'Setz mich ab, Dick! } \\
\text { Mir wird schwindlig', } \\
\text { befahl sie. [commanded] }\end{array}$ \\
\hline 8 & $\begin{array}{l}\text { C: } \backslash \text { MULTIC } 1 \backslash \text { scott.en } \\
\text { P3518 S1 } \\
\text { 'Why, the insolence!' } \\
\text { insisted Anthony ner- } \\
\text { vously, ,the insolence!' }\end{array}$ & $\begin{array}{l}\text { C: } \backslash \text { MULTIC } 1 \backslash \text { scott.de } \\
\text { P3518 } \\
\text { 'Also wirklich, was für eine } \\
\text { Frechheit!' beharrte } \\
\text { Anthony nervös. <s> 'Was } \\
\text { für eine Frechheit!' }\end{array}$ & $\begin{array}{l}\text { C: } \backslash \text { MULTIC } 1 \backslash \text { scott.es } \\
\text { P3518 } \\
\text { 'Diese Frechheit', schäumte } \\
\text { Anthony. <s> 'Eine solche } \\
\text { Frechheit.. } \\
\text { [fumed] }\end{array}$ \\
\hline 9 & $\begin{array}{l}\text { C: \MULTIC } 1 \backslash \text { scott.en } \\
\text { P3605 S1 } \\
\text { 'Not too drunk talk to you,' } \\
\text { insisted Anthony with a } \\
\text { leer. }\end{array}$ & $\begin{array}{l}\text { C: \MULTIC } 1 \backslash \text { scott.de } \\
\text { P3605 } \\
\text { 'Nicht zu betrunken, um } \\
\text { mit Ihnen zu reden', } \\
\text { beteuerte Anthony mit } \\
\text { einem tückischen } \\
\text { Seitenblick. }\end{array}$ & $\begin{array}{l}\text { C: } \backslash \text { MULTIC } 1 \backslash \text { scott.es } \\
\text { P3605 } \\
\text { 'Nich zu betrunken, um } \\
\text { mit Ihn' zu reden', brachte } \\
\text { Anthony grinsend hervor. } \\
\text { [said/managed to say] }\end{array}$ \\
\hline 10 & $\begin{array}{l}\text { C: \MULTIC } 1 \backslash \text { scott.en } \\
\text { P3508 S1 } \\
\text {,Why not him?` he insisted } \\
\text { callously. }\end{array}$ & $\begin{array}{l}\text { C: \MULTIC 1 } \backslash \text { scott.de } \\
\text { P3508 } \\
\text { 'Warum nicht der?' } \\
\text { beharrte er gefühllos. }\end{array}$ & $\begin{array}{l}\text { C: } \backslash \text { MULTIC } 1 \backslash \text { scott.es } \\
\text { P3508 Aber er ließ nicht } \\
\text { locker. }<\text { s }>\text { 'Warum nicht?' } \\
\text { fragte er brutal. [asked] }\end{array}$ \\
\hline
\end{tabular}

Oeser mainly sticks to the verbs beharrte (maintaining forcefully), in six instances, and behauptete (stating forcefully), in two instances, which can be counted as obvious translations for insisted. In two instances he chooses beteuerte (protested/assured), which keeps the meaning of maintaining or stating, but slightly loses the aspect of force. Orth-Guttmann, however, uses beharte and beteuerte only once (Nos. 1 and 2). In No. 3, she omits the reporting clause. She expresses the aspect of 'forcefully stating' by using an exclamation mark and the particle natürlich (of course) in the utterance. With widersprach (contradicted) and konterte (countered), in Nos. 4 and 5, she chooses verbs which focus on the conflicting element of the situation and make the logical structure of the source text more explicit (statement B contradicts statement 
A). In Nos. 6 and 7, Orth-Guttmann emphasizes the preceding utterances by choosing stronger verbs, which express demand (verlangte) and order (befahl), respectively. In No. 8, she goes one step further by choosing schäumte (fumed), which is not only stronger than insisted, but also turns the speaker's nervousness into rage. In this case, she interprets the emotional state of the character in the novel beyond the source text's indication. Taking the context into account, it is not unlikely that the speaker felt rage as well as nervousness in that particular instance. Nevertheless Fitzgerald had decided to point out the nervousness rather than the anger of the character. At a first glance the verb chosen by Orth-Guttmann in No. 9 seems to be quite neutral. However, in connection with her abbreviations (Nich [Nicht], Ihn' [Ihnen]) in the utterance, accounting for the ungrammatical structure of the source text, and taking into account the fact that the character (Anthony) was drunk, the verb brachte hervor (said/managed to say) implies difficulty in speaking and it loses the aspect of persistence and force. In this example she changes the focus of the character's condition or attitude again. In No. 10 Orth-Guttmann chooses the verb fragte (asked), but compensates for the loss of meaning by adding a narrative sentence preceding the direct speech act in which she uses ließ nicht locker (did not give up). By this method she keeps the meaning of insisted.

The example of the speech-act report verb insisted shows that Oeser stays closer to the source text and uses more repetition than Orth-Guttmann. Orth-Guttmann uses a lot of variation and moves much further from the source text than Oeser. From the examination of her translations of insisted, a possible hypothesis might be that she tends to explicitate or even interpret the source text.

\section{Possible interpretations}

On the basis of the analyses described above, I would like to propose three tentative conclusions: (i) Oeser uses lexical repetition more than Orth-Guttmann, who tends to avoid repetition; (ii) Oeser stays closer to the source text than Orth-Guttmann; and (iii) Orth-Guttmann tends to explicitate.

(i) There is a significant difference in the number of instances of repetition between the two translators (see Tables 2-4). Oeser repeats verbs he chooses as translations of a particular speech-act report verb to a considerably greater extent than Orth-Guttmann. She uses a significantly wider variety of verbs to translate the individual speech-act report verbs and consequently repeats these verbs to a lesser extent. She also frequently omits the reporting clause before or after an utterance, in order to avoid repeating the particular verb. Orth-Guttmann may be motivated by a desire to avoid what is seen by some commentators as bad style. Ben-Ari (1998) says about repetition:

[...] it seems that avoiding repetitions has to do with a deep-rooted need to display richness of vocabulary, passed down by generations of normative stylistic do's and don'ts and [is] extremely difficult to root out. [...] It seems that, from kindergarten on, pupils have been complimented on their rich vocabulary and reprimanded for repetitiveness. (Ben-Ari 1998: 70)

(ii) Oeser uses verbs repeatedly according to the instances of repetitions of speech-act report verbs in the source text. He stays close to the source text and in the majority of cases chooses verbs which produce quite literal translations of the speech- 
act report verb. Orth-Guttmann, on the other hand, does not keep up the repetitions she encounters in the source text, but tries to avoid them by variation and omissions of reporting clauses.

(iii) Orth-Guttmann uses a greater variety of speech-act report verbs to translate the 19 verbs under investigation. A considerable number of these verbs deviate from the semantic meaning of the source-text verb. In some instances she chooses a verb less specific than that in the source text. However, in the majority of instances, she chooses a verb with an additional semantic feature. Like the translators studied by Bourne (2002) who found 'considerable diversity in the choice of Spanish verbs used to render 'said' in the context of impositive directive speech acts' (Bourne 2002: 241) OrthGuttmann intervenes 'to provide variety, to convey precision and to specify the illocutionary force of an utterance' (Bourne 2002: 252). Orth-Guttmann also appears to use speech-act report verbs to emphasize characters' emotional states to the extent that she influences the reader's attitude to the characters in a manner consistent with that described by Burgess (2000) in his discussion of Goethe's Die Wahlverwandtschaften.

\section{Concluding remarks}

The analyses carried out show significant differences in the use of speech-act report verbs between the two translators. Hans-Christian Oeser repeats the speech-act report verbs in congruence with the source text. It is likely that he was aware of the repetitions in the source text and retained them deliberately. Renate Orth-Guttmann also noticed the source text repetitions. It is often argued that translators avoid repetition (Laviosa-Braithwaite 1998). Orth-Guttmann was aware of the accepted wisdom that repeated use of speech-act report verbs, particularly sagte (said), is considered to be bad style, or as Orth-Guttmann (personal communication, July 2005) put it, that German readers do not like the repetition of sagte. Thus, OrthGuttmann's strategy conforms to perceived target-language conventions by avoiding too much repetition. Oeser uses repetition as a stylistic device which runs counter to current conventions.

Orth-Guttmann's extensive use of variation goes together with her choices of verbs with an additional semantic feature, with a potentially different illocutionary force. Thus she highlights certain traits of the characters (see Table 6, Nos. 4-9). The question remains, however, as to whether she does this systematically and to such an extent that the readers of her translation would perceive the characters differently from those of Oeser's translation.

\section{ACKNOWLEDGEMENTS}

I would like to thank Dr. Dorothy Kenny and Dr. Gabriela Saldanha of Dublin City University for their helpful comments on an earlier draft of this paper. I would also like to thank the Irish Research Council for the Humanities and Social Sciences for funding my PhD project, in the framework of which the present study was carried out.

\section{NOTES}

1. The present paper was written in 2004 when Wordsmith Tools 4.0 had not yet been released. Thus the analysis described in this paper is based on Version 3.0.

2. Austin does not provide empirical evidence for this assertion. 
3. Short uses the term 'direct speech' to label both the superordinate concept also known here as direct speech, and the subordinate concept known here (to avoid confusion) as reported direct speech.

\section{REFERENCES}

Austin, J. L. (1976 [1962]): How to do things with Words, Oxford, Oxford University Press.

BAKER, M. (2000): “Towards a Methodology for Investigating the Style of a Literary Translator," Target 12-2, Amsterdam and Philadelphia, Benjamins B. V., p. 241-266.

Ballmer, T. and W. Brennenstuhl (1981): Speech Act Classification, Berlin and Heidelberg, Springer-Verlag.

BEN-ARI, N. (1998): "The ambivalent case of repetitions in literary translation. Avoiding repetitions: a 'universal' of translation?," META 43-1, Montréal, Les Presses de l'Université de Montréal, p. 68-78.

Bourne, J. (2002): "He said, she said. Controlling illocutionary force in the translation of literary dialogue," Target 14-2, Amsterdam and Philadelphia, Benjamins B. V., p. 241-261.

Burgess, G. J. A. (2000): "Corpus analysis in the service of literary criticism: Goethe's Die Wahlverwandtschaften as a model case," in DodD, B. (ed): Working with German corpora, Birmingham, University of Birmingham Press, p. 40-68.

Collins. Dictionary of the English Language (1994): 3rd edn. updated, Glasgow, Harper Collins Publishers.

Duden. Die deutsche Rechtschreibung (2000): Vol. 1, 22nd edn., Mannheim [etc.], Dudenverlag.

Fitzgerald, F. S. (1922): The Beautiful and Damned, New York, Scribner's.

Fitzgerald, F. S. (1998): Die Schönen und Verdammten, Zürich, Diogenes. [Translated by H.-C. Oeser.]

Fitzgerald, F. S. (1998): Die Schönen und Verdammten, Zürich, Manesse. [Translated by R, Orth-Guttmann.]

Laviosa-Braithwaite, S. (1998): "Universals of translation," in Baker, M. (ed.): Routledge Encyclopedia of Translation Studies, London and New York, Routledge, p. 77-80.

Pons. Großwörterbuch für Experten der Universität. Englisch-Deutsch, Deutsch-English (2001), Stuttgart, Klett Verlag.

Sсотт, M. (1998): Wordsmith Tools, Version 3.0, Oxford, Oxford University Press.

Short, M., Semino, E. and J. Culpeper (1996): "Using a corpus for stylistics research: speech and thought presentation," in Thомas, J. and M. Short (eds): Using Corpora for Language Research, London and New York, Longman, p. 110-131.

Woolls, D. (1997): Multiconcord Version 1.5, Birmingham, CFL Software Development. 